\title{
Incidence of leukaemia in young people in the vicinity of Hinkley Point nuclear power station, 1959-86
}

\author{
P D Ewings, C Bowie, M J Phillips, S A N Johnson
}

Department of Public Health, Somerset Health Authority, Taunton, Somerset P D Ewings, PHD, district statistician

$\mathrm{C}$ Bowie, FFCM, director of public health

Department of

Haematology, Musgrove Somerset

M J Phillips, FRCPATH, consultant haematologist S A N Johnson, MRCPATH, consultant haematologist

Correspondence to:

Dr P D Ewings, District

Headquarters, Somerset

Health Authority, Taunton,

Somerset TA2 7PQ.

Br Med f 1989;299:289-93
Park Hospital, Taunton,

\begin{abstract}
The incidence of leukaemia and non-Hodgkin's lymphoma in young people (aged under 25) living in a predefined area around the nuclear power station at Hinkley Point, Somerset, was examined for the period $1959-86$ by using cancer registry data. During the period since Hinkley Point began operationsthat is, 1964-86-there were 19 cases in the area compared with 10.4 expected from national rates, giving a standardised registration ratio of $1.82(95 \%$ confidence interval $1 \cdot 10$ to $2 \cdot 85$ ). The incidence in the rest of Somerset was also high, however (standardised registration ratio $1 \cdot 18 ; 95 \%$ confidence interval 0.98 to 1.41 ), and the high rate around Hinkley Point may simply have been reflecting the high local incidence (ratio of the two standardised registration ratio's $1.54 ; 95 \%$ confidence interval $\mathbf{0 . 9 0}$ to 2.52 ). Analysis of predetermined five year periods showed that the excess cases in the Hinkley Point area were concentrated in the 10 years 1964-73 after commissioning of the station, at a time when rates in the rest of Somerset were close to the national average. In particular the nine cases occurring in the five years 1969-73 were about four times the number expected from national rates (standardised registration ratio $3.96 ; 95 \%$ confidence interval 1.81 to 7.52). Rates in the Hinkley Point area after 1973 were fairly low, especially as compared with the rest of Somerset. In the five years 1959-63 (that is, before Hinkley Point was commissioned) rates throughout
\end{abstract}

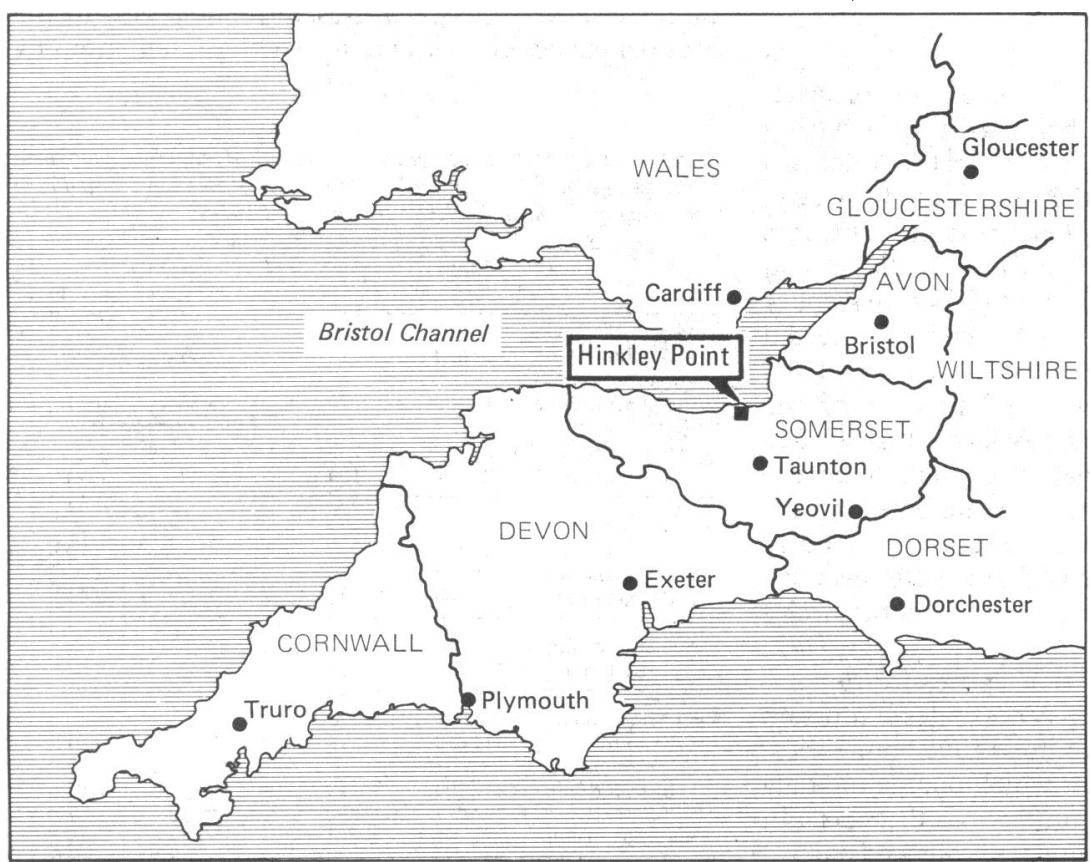

FIG 1 - Location of Hinkley Point
Somerset (including the Hinkley Point area) were higher than the national rate.

These findings should be interpreted with caution, and further studies are required to test the plausibility of theories relating to radiation and viruses.

\section{Introduction}

In the past five years there has been much discussion about the incidence of cancer, and in particular childhood leukaemia, in the vicinity of nuclear installations. ${ }^{1-6}$ Hinkley Point is a nuclear installation situated on the north coast of Somerset (fig 1). It contains two nuclear power stations: station $\mathrm{A}$, containing two magnox reactors commissioned in 1964; and station B, containing two advanced gas cooled reactors commissioned in 1977. A public inquiry is currently taking place into the proposed building of a third station, which would use a pressurised water reactor.

The incidence of leukaemia has been the subject of three internal reports to the Somerset Health Authority. ${ }^{7.4}$ The rates quoted in these reports were calculated by using a locally compiled register of patients of all ages developing the disease in the catchment area of Musgrove Park Hospital, Taunton, since 1971. The Leukaemia Research Fund's centre for clinical epidemiology had supplied expected numbers of cases based on their study covering a large part of Britain. ${ }^{10} 11$ Our reports identified a high prevalence of leukaemia throughout the study area when compared with the Leukaemia Research Fund's data. For example, even if attention was confined to the three years for which Leukaemia Research Fund data were available (1984-6) the 111 cases of leukaemia in people under 85 years of age in the study area were $61 \%$ more than expected (standardised incidence ratio 1.61 ; $95 \%$ confidence interval 1.32 to $1 \cdot 94$ ).

Analyses of the geographical distribution of cases on the local register found no evidence of clustering. In particular, rates in the vicinity of Hinkley Point were not unduly high, though no specific hypothesis was formulated regarding the nuclear installation. The third Somerset Health Authority report, however, contained an additional analysis testing a specific hypothesis about leukaemia in young people living in the vicinity of Hinkley Point by using cancer registry data. This paper reports the results.

A prior hypothesis requires exact definition of time period, geographical boundary, diagnosis, methods of analysis, etc. Clusters of cases can quite easily be established if, for example, geographical boundaries are selected after inspection of the data. ${ }^{12}$ In this study the methods employed follow as closely as possible those used in recent analyses of data relating to the Dounreay nuclear establishment in Caithness. ${ }^{56}$ This ensures a degree of objectivity in that the decisions regarding geographical boundaries and so on are established in advance. 


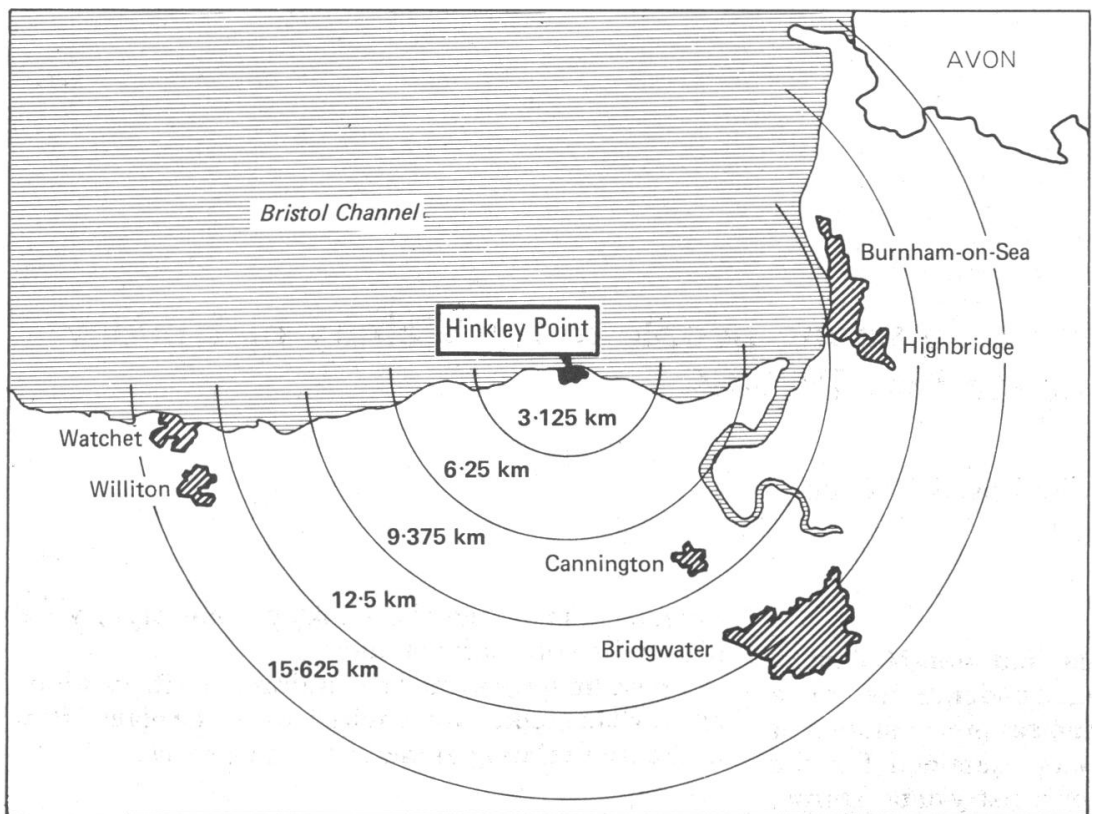

FIG 2-Zones around Hinkley Point used in analysis showing main centres of population

\section{Subjects and methods}

The South Western Regional Cancer Registry was used to identify cases registered in the current Somerset health district since 1959. All cases of leukaemia and non-Hodgkin's lymphoma in patients aged under 25 at the time of registration were included. As in the Dounreay analysis undertaken by the Committee on Medical Aspects of Radiation in the Environment, ${ }^{6}$ cases of non-Hodgkin's lymphoma were included because of possible confusion in the past between certain types of leukaemia and non-Hodgkin's lymphoma. A total of 169 cases were identified, 121 registered as leukaemia and 48 as non-Hodgkin's lymphoma.

\section{TIME PERIODS}

The main time period of interest was that since Hinkley Point began operations - that is, 1964-86. Conventional five year periods centred on census years were also used, including the five year period 1959-63 before the commissioning of station $\mathrm{A}$.

\section{GEOGRAPHICAL AREAS}

The original Dounreay analysis used concentric circles around the nuclear establishment to construct areas for study. ${ }^{5}$ Successive halving of an arbitrary starting figure of $100 \mathrm{~km}$ resulted in circles of radii 25 and $12.5 \mathrm{~km}$ as the basis for the main areas for study. In a sensitivity analysis the Dounreay investigators continued the halving process down to $3.125 \mathrm{~km}$ and indeed used all radii from $3.125 \mathrm{~km}$ to $25 \mathrm{~km}$ in steps of $3.125 \mathrm{~km} .{ }^{6}$ In our study the $12.5 \mathrm{~km}$ circle was selected to produce the main area of interest. Other radii from $3.125 \mathrm{~km}$ to $15.625 \mathrm{~km}$ were used to monitor the sensitivity of the main choice. Radii larger than 15.625 $\mathrm{km}$ would have complicated matters by including parts of Avon and Wales and indeed were unnecessary; the Hinkley Point area was not as sparsely populated as that around Dounreay and the $12 \cdot 5 \mathrm{~km}$ circle covered a sufficiently large population. Figure 2 shows the circles selected.

The requirement of population figures for denominators in calculating incidences necessitates contortion of the selected circles to fit administrative boundaries. Generally the smallest areas for which population data are available are census enumeration districts. In Scotland these are conterminous with postcode areas, and the postcoding of all cases on the Scottish Cancer
Registry since 1968 therefore made the calculation of incidences for small areas fairly straightforward for the Dounreay investigators. In England and Wales no such conterminosity exists between enumeration districts and postcode areas. Moreover, for the three censuses spanning the period covered by this study enumeration districts changed, especially in areas of substantial development. This study therefore used the smallest administrative areas in practicable terms - that is, civil parishes and electoral wards. Parishes are generally smaller than wards in rural areas, but wards were used where the $12.5 \mathrm{~km}$ circle transected the town of Bridgwater. The selected circles were thus contorted to fit parish and ward boundaries according to whether the greater part of each administrative area appeared to lie within the circle. For the $12.5 \mathrm{~km}$ circle a total of 25 parishes and wards were included.

\section{STATISTICAL METHODS}

Population figures for the circular areas around Hinkley Point and (for consistency) for the rest of the Somerset health district were calculated from the small area statistics available at parish and ward level at the time of the 1961, 1971, and 1981 censuses. The small area statistics are actually inconsistent with population estimates (the population estimate for Somerset in 1981 was about 3\% higher than the small area statistics equivalent), but population estimates as such are not available for parishes and wards and the use of small area statistics is unlikely to introduce substantial error. Linear interpolation was used to produce population figures for years between the censuses and backwards extrapolation for 1959 and 1960. A reversal in birth trends in recent years made simple forward extrapolation from the 1971-81 trend unrealistic. Population figures for 1982-6 were obtained instead by changing the 1981 small area statistics figures in proportion to the changes in population estimates since 1981 for the smallest areas available - namely, the appropriate district council areas.

National cancer registry rates in five year age and sex bands were used to obtain the expected number of cases in the areas studied. Published rates are available for each year from 1961 to 1984 inclusive. Rates for 1959 and 1960 were estimated as the average of the rates for the 10 years 1961-70. Similarly the 10 year period 1975-84 was used to estimate the rates for 1985 and 1986. Standardised registration ratios were calculated in the usual way by dividing the observed number of cases in a given area and time period by the number expected. In accordance with presentations by

TABLE I-Registrations of leukaemia and non-Hodgkin's lymphoma in people aged under 25 within $12.5 \mathrm{~km}$ radius of Hinkley Point and in remainder of Somerset health district during 1964-86

\begin{tabular}{|c|c|c|c|c|}
\hline & $\begin{array}{c}1981 \\
\text { Population }\end{array}$ & No of cases & $\begin{array}{c}\text { Expected No } \\
\text { (national rates) }\end{array}$ & p Value \\
\hline $\begin{array}{l}\text { Leukaemia } \\
<12 \cdot 5 \mathrm{~km} \\
\text { Somerset health } \\
\text { district residue }\end{array}$ & $\begin{array}{r}12670 \\
112700\end{array}$ & 87 & $75 \cdot 56$ & $0 \cdot 11$ \\
\hline $\begin{array}{l}\text { Somerset health } \\
\text { district total }\end{array}$ & 125370 & 100 & 83.47 & 0.043 \\
\hline $\begin{array}{l}\text { Non-Hodgkin's lym } \\
<12 \cdot 5 \mathrm{~km} \\
\text { Somerset health } \\
\text { district residue }\end{array}$ & $\begin{array}{l}\text { phoma } \\
12670 \\
112700\end{array}$ & 31 & $\begin{array}{c}2 \cdot \cdot \\
24 \cdot 37\end{array}$ & $\begin{array}{l}0.043 \\
0.11\end{array}$ \\
\hline $\begin{array}{l}\text { Somerset health } \\
\text { district total }\end{array}$ & 125370 & 37 & $26 \cdot 88$ & 0.037 \\
\hline $\begin{array}{l}\text { Leukaemia and non- } \\
<12.5 \mathrm{~km} \\
\text { Somerset health } \\
\text { district residue }\end{array}$ & $\begin{array}{c}- \text { Hodgkin's ly } \\
\quad 12670 \\
112700\end{array}$ & $\begin{array}{c}\text { ymphoma } \\
19\end{array}$ & $10 \cdot 42$ & $0 \cdot 011$ \\
\hline $\begin{array}{l}\text { Somerset health } \\
\text { district total }\end{array}$ & 125370 & 137 & 110.35 & $0 \cdot 0079$ \\
\hline
\end{tabular}


the Committee on Medical Aspects of Radiation in the Environment," for example, statistical significance was assessed by using the one sided cumulative Poisson probability of obtaining the observed number of cases (or more) given the expected number. To explore the likely range of values, however, confidence intervals are also presented when appropriate.

We know from our previous work that there is a high incidence of leukaemia (at all ages) throughout the west of Somerset." "It may be the case that any observed excess of cases in the specific areas around Hinkley Point relative to national rates may simply be a reflection of high rates throughout this area. Standardised registration ratios for the whole of Somerset were therefore calculated as an indicator of local incidence generally. When appropriate, direct comparison between the rate in the Hinkley Point area and that for the rest of Somerset is made, using results on independent Poisson variables - that is, the number of cases in the Hinkley Point area, conditional on the total number of cases in Somerset, should behave according to the binomial distribution.

\section{Results}

A total of 22 cases were registered in the $12.5 \mathrm{~km}$ area between 1959 and 1986, three of these occurring before Hinkley Point was commissioned in 1964. The cases were spread throughout the $12.5 \mathrm{~km}$ area without concentration in any particular patch. They also covered the entire age range under study, the youngest patient being 1 year old at registration and the oldest 24

Main hypothesis-Table I shows the main results relating to the $12.5 \mathrm{~km}$ area around Hinkley Point for

TABLI: II --Standardised registration ratios (95\% confidence intervals) for 1964-86 (people aged under 25)

\begin{tabular}{|c|c|c|}
\hline & Lecukaemia & $\begin{array}{c}\text { Leukaemia and } \\
\text { Non-Hodgkin's lymphoma non-Hodgkin's lymphoma }\end{array}$ \\
\hline \multirow{3}{*}{$\begin{array}{l}<12.5 \mathrm{~km} \\
\text { Somerset health district residue } \\
\text { Ratio of } 12.5 \mathrm{~km} \text { area to Somerset } \\
\text { health district residue }\end{array}$} & $1.64(0.88102 .81)$ & $1.82(1.10$ to 2.85$)$ \\
\hline & $1.15(0.92$ to 1.42$)$ & $1.27(0.86$ 10 1.81$)$. \\
\hline & $1.43(0.73$ to 2.57 & $1 \cdot 88: 0.64$ to 4.57$)$ \\
\hline
\end{tabular}

TABI.F III - Registrations of leukaemia and non-Hodgkin's lymphoma during 1964-86 in people aged under 25. Sensitivity to choice of geographical boundary (figures in parentheses are $95 \%$ confidence intervals)

\begin{tabular}{|c|c|c|c|c|}
\hline & 1981 Population & No of cases & Standardised registration ratio & p V'alue \\
\hline \multicolumn{5}{|l|}{ Leukacmia } \\
\hline$-3.125 \mathrm{~km}$ & 420 & 1 & $3 \cdot 23(0 \cdot 081017 \cdot 97)$ & $0 \cdot 27$ \\
\hline$<6.25 \mathrm{~km}$ & 840 & 1 & $1.75(0.04$ to $9 \cdot 77)$ & $0 \cdot 43$ \\
\hline$=9.375 \mathrm{~km}$ & 2440 & 4 & $2.34(0.64$ to 5.99$)$ & 0.095 \\
\hline$-12.5 \mathrm{~km}$ & 12670 & 13 & $1.64(0.88$ to $2 \cdot 81)$ & $0 \cdot 060$ \\
\hline$<15.625 \mathrm{~km}$ & 25130 & 22 & $1.37(0.86$ to $2 \cdot 08)$ & $0 \cdot 091$ \\
\hline \multicolumn{5}{|l|}{ Somerset health } \\
\hline district residuc & 100240 & 78 & $1 \cdot 16(0.91$ to 1.44$)$ & $0 \cdot 11$ \\
\hline Somerset health & 125370 & 100 & $1.20(0.97$ to 1.46$)$ & $0 \cdot 043$ \\
\hline \multicolumn{5}{|c|}{ Non-Hodgkin’s lymphoma } \\
\hline$<3.125 \mathrm{~km}$ & 420 & 0 & $0(0$ to $37 \cdot 85)$ & $1 \cdot 0$ \\
\hline$<6.25 \mathrm{~km}$ & 840 & 0 & $0(0$ to $20 \cdot 85)$ & $1 \cdot 0$ \\
\hline $9.375 \mathrm{~km}$ & 2440 & 1 & $1.82(0.05$ to 10.15$)$ & $0 \cdot 142$ \\
\hline$-12.5 \mathrm{~km}$ & 12670 & 6 & $2.39(0.88$ to $5 \cdot 20)$ & $0 \cdot 043$ \\
\hline$<15.625 \mathrm{~km}$ & 25130 & 11 & $2 \cdot 15(1.08$ to 3.86$)$ & $0 \cdot 016$ \\
\hline \multicolumn{5}{|l|}{ Somerset health } \\
\hline district residuc & 100240 & 26 & $1.19(0.78$ to 1.75$)$ & $0 \cdot 209$ \\
\hline \multicolumn{5}{|l|}{ Somerset health } \\
\hline \multicolumn{5}{|c|}{ Leukacmia and non-Hodgkin's lymphoma } \\
\hline$<3.125 \mathrm{~km}$ & 420 & 1 & $2.46(0.06$ to 13.69$)$ & $0 \cdot 33$ \\
\hline$<6.25 \mathrm{~km}$ & 840 & 1 & $1.34(0.03$ to 7.46$)$ & 0.53 \\
\hline$<9.375 \mathrm{~km}$ & 2440 & 5 & $2.21(0.72$ to 5.16$)$ & 0.079 \\
\hline$<12.5 \mathrm{~km}$ & 12670 & 19 & $1.82(1.10$ to 2.85$)$ & 0.011 \\
\hline$<15.625 \mathrm{~km}$ & 25130 & 33 & $1.56(1.07$ to $2 \cdot 19)$ & $0 \cdot 010$ \\
\hline \multicolumn{5}{|l|}{ Somerset health } \\
\hline $\begin{array}{l}\text { Somerset health } \\
\text { district total }\end{array}$ & 125370 & 137 & $1.24(1.04$ to 1.47$)$ & 0.0079 \\
\hline
\end{tabular}

the period 1964-86. The conventional $\mathrm{p}$ value shows that the rate for the $12 \cdot 5 \mathrm{~km}$ area was significantly high for leukaemias and non-Hodgkin's lymphomas combined, but so too was the rate for the rest of the Somerset health district at the 5\% level. The Hinkley Point area may simply have been reflecting high rates throughout Somerset. Clearly the important comparison was between the $12 \cdot 5 \mathrm{~km}$ area and the rest of the Somerset health district. Table II gives the standardised registration ratios for the two areas based on the national rates and a relative risk for the $12 \cdot 5 \mathrm{~km}$ area compared with the Somerset health district residue based on the ratio of the two standardised registration ratios. ${ }^{13}$ Though the Hinkley Point area had higher rates than the rest of Somerset, these rates were within the bounds of random fluctuation in Somerset. The one sided $p$ values for the $12.5 \mathrm{~km}$ area compared with the Somerset health district residue were 0.15 for leukaemia, $0 \cdot 13$ for non-Hodgkin's lymphoma, and 0.058 for both combined.

Changing geographical boundaries-Table III shows the results of using circles around Hinkley Point of varying radii. Note that "Somerset health district residue" was that part of the Somerset health district outside the $15.625 \mathrm{~km}$ area and as such was different from that used in tables I and II. For leukaemias and non-Hodgkin's lymphomas combined the standardised registration ratio for every area around Hinkley Point was greater than 1.0 and greater than that for the rest of the Somerset health district. Direct comparison with the Somerset health district residue gave a relative risk of 1.33 for the $15.625 \mathrm{~km}$ area $(95 \%$ confidence interval 0.88 to 1.99 ) with a one sided $\mathrm{p}$ value of 0.090 . Thus the problem of interpretation remained, in that the rates around Hinkley Point may simply have been reflecting high rates throughout Somerset. This sensitivity analysis confirms, however, that the choice of the $12.5 \mathrm{~km}$ circle as the main area did not produce any peculiarities and that the area seemed to reflect incidence in the vicinity of Hinkley Point.

Changing time periods - Table IV gives the results for the $12.5 \mathrm{~km}$ area for conventional five year periods. Standardised registration ratios are given for this area and the Somerset health district residue based on national rates, and the ratio of the two standardised registration ratios is also given. The excess cases for the $12.5 \mathrm{~km}$ area were concentrated in the 10 years after the commissioning of Hinkley Point - that is, 1964-73. In particular, the rate for 1969-73 was about four times that expected from national rates, with an associated one sided $p$ value of 0.00059 (that is, about one in 1700). Interestingly, the rates for the rest of Somerset during the 10 years were close to the national average. Rates for the Hinkley Point area subsequent to 1973 were fairly low, especially compared with the rest of Somerset. It is also noteworthy that rates throughout Somerset (including the $12.5 \mathrm{~km}$ area) were fairly high before Hinkley Point began operations.

\section{Discussion}

The cancer registry system has some deficiencies, ${ }^{14}{ }^{15}$ and this is particularly true for the earlier years covered in this study. It is implicitly assumed in such studies that the completeness and accuracy of the register for the area under study are comparable to the area used for comparison. Examinations of a local register started in 1971 showed that, of 48 cases of leukaemia in the under 25 year age group in part of Somerset (specifically the catchment area of Musgrove Park Hospital in Taunton), four cases were missing from the regional cancer registry. We cannot be certain whether this omission rate is close to the national average. Possibly Somerset has higher reporting rates than the national average, but it is unlikely that the area around Hinkley 


\begin{tabular}{|c|c|c|c|c|c|c|}
\hline & \multicolumn{2}{|c|}{ Leukaemia } & \multicolumn{2}{|c|}{$\begin{array}{l}\text { Non-Hodgkin's } \\
\text { lymphoma }\end{array}$} & \multicolumn{2}{|c|}{$\begin{array}{l}\text { Leukaemia and } \\
\text { non-Hodgkin's } \\
\text { lymphoma }\end{array}$} \\
\hline & $\begin{array}{l}\text { Observed } \\
\text { registrations }\end{array}$ & $\begin{array}{l}\text { Standardised } \\
\text { registration ratio }\end{array}$ & $\begin{array}{l}\text { Observed } \\
\text { registrations }\end{array}$ & $\begin{array}{l}\text { Standardised } \\
\text { registration ratio }\end{array}$ & $\begin{array}{l}\text { Observed } \\
\text { registrations }\end{array}$ & $\begin{array}{l}\text { Standardised } \\
\text { registration ratio }\end{array}$ \\
\hline \multicolumn{7}{|l|}{$1959-63$} \\
\hline$<12.5 \mathrm{~km}$ & 2 & $1.59(0.19$ to 5.74$)$ & 1 & $2.09(0.05$ to 11.65$)$ & 3 & $1.73(0.36$ to 5.05$)$ \\
\hline Somerset health district & 19 & $1.47(0.89$ to 2.30$)$ & 10 & $1.99(0.96$ to 3.66$)$ & 29 & $1.62(1.08$ to 2.32$)$ \\
\hline $\begin{array}{l}\text { Ratio of standardised } \\
\text { registration ratios }\end{array}$ & - & $1.08(0.12$ to 4.49$)$ & - & $1.05(0.02$ to 7.39$)$ & - & $1.07(0.21$ to 3.44$)$ \\
\hline \multicolumn{7}{|l|}{$1964-8$} \\
\hline$<12.5 \mathrm{~km}$ & 4 & $2.96(0.81$ to 7.59$)$ & 1 & $1.75(0.04$ to 9.74$)$ & 5 & $2.60(0.85$ to 6.08$)$ \\
\hline Somerset health district & 17 & $1 \cdot 26(0.73$ to $2 \cdot 01)$ & 3 & $0.52(0.11$ to 1.51$)$ & 20 & $1.04(0.63$ to 1.60$)$ \\
\hline $\begin{array}{l}\text { Ratio of standardised } \\
\text { registration ratios }\end{array}$ & - & $2.35(0.58$ to 7.22$)$ & - & $3.37(0.06$ to 42.20$)$ & - & $2.50(0.74$ to 6.91$)$ \\
\hline \multicolumn{7}{|l|}{$1969-73$} \\
\hline$<12.5 \mathrm{~km}$ & 7 & $4.01(1.61$ to 8.24$)$ & 2 & $3.81(0.46$ to 13.75$)$ & 9 & $3.96(1.81$ to 7.52$)$ \\
\hline Somerset health district & 16 & $0.94(0.54$ to 1.52$)$ & 5 & $0.96(0.31$ to 2.24$)$ & 21 & $0.94(0.58$ to 1.44$)$ \\
\hline $\begin{array}{l}\text { Ratio of standardised } \\
\text { registration ratios }\end{array}$ & - & $4.27(1.48$ to 10.94$)$ & - & $3.97(0.38$ to $24 \cdot 30)$ & - & $4.21(1.69$ to 9.60$)$ \\
\hline \multicolumn{7}{|l|}{$1974-8$} \\
\hline$<12.5 \mathrm{~km}$ & 0 & $0 \quad(0$ to 1.89$)$ & 1 & $1.93(0.05$ to $10 \cdot 75)$ & 1 & $0.41(0.01$ to $2 \cdot 26)$ \\
\hline Somerset health district & 24 & $1.32(0.84$ to 1.96$)$ & 10 & $2.04(0.98$ to 3.75$)$ & 34 & $1.47(1.02$ to 2.06$)$ \\
\hline $\begin{array}{l}\text { Ratio of standardised } \\
\text { registration ratios }\end{array}$ & - & $0 \quad(0$ to 1.55$)$ & - & $0.95(0.02$ to 6.67$)$ & - & $0.28(0.01$ to 1.64$)$ \\
\hline \multicolumn{7}{|l|}{ 1979-83 } \\
\hline$<12.5 \mathrm{~km}$ & 2 & $1 \cdot 14(0 \cdot 14$ to $4 \cdot 10)$ & 1 & $1.78(0.04$ to 9.89$)$ & 3 & $1.29(0.27$ to 3.78$)$ \\
\hline Somerset health district & 17 & $1.07(0.62101 .71)$ & 10 & $1.93(0.93$ to 3.56$)$ & 27 & $1.28(0.84 t 0) 1.86)$ \\
\hline $\begin{array}{l}\text { Ratio of standardised } \\
\text { registration ratios }\end{array}$ & - & $1 \cdot 07(0 \cdot 12$ to $4 \cdot 48)$ & - & $0.92(0.02$ to 6.46$)$ & - & $1.01(0.20$ to 3.28$)$ \\
\hline \multicolumn{7}{|l|}{$1984-6$} \\
\hline$<12.5 \mathrm{~km}$ & 0 & $0 \quad(0$ to $3 \cdot 32)$ & 1 & $3.00(0.08$ to 16.73$)$ & 1 & $0.69(0.02$ to 3.87$)$ \\
\hline Somerset health district & 13 & $1.20(0.64$ to 2.05$)$ & 3 & $0.91(0.19$ to 2.66$)$ & 16 & $1.13(0.65$ to 1.84$)$ \\
\hline $\begin{array}{l}\text { Ratio of standardised } \\
\text { registration ratios }\end{array}$ & - & $0 \quad(0 \pm 03 \cdot 37)$ & - & $3 \cdot 30(0.07$ to $43 \cdot 63)$ & - & $0.61(0.0210+\cdot 16)$ \\
\hline
\end{tabular}

Point has reporting rates vastly different from the rest of Somerset. Nevertheless, the small numbers in our series can make just one error alter the significance of a result considerably.

The methods used in the Dounreay analysis were adopted in this study to ensure a degree of objectivity. There is, however, one aspect that was not replicated namely, the justification for using the Poisson model for describing the distribution of leukaemia cases in the study area. The Poisson distribution is appropriate if events occur randomly in time and space throughout a population. If, however, this is not the case (for example, a disease caused by a virus might be expected to occur in time-space "clusters") then a higher than average incidence in a given area and time period would not be as rare as the Poisson model would suggest. Indeed, variation in excess of that expected from Poisson theory has been found in a recent study of mortality from leukaemia. ${ }^{16}$

In the Dounreay analysis the investigators justified using the Poisson model by showing that randomly constructed areas throughout Scotland of similar size to the area studied around Dounreay contained numbers of cases of leukaemia that were consistent with numbers from a Poisson distribution. Similarly, in the report by the independent advisory group chaired by Sir Douglas Black the distribution of leukaemia in rural districts throughout England and Wales similar to the one under study (Millom rural district, near the Sellafield nuclear plant) was found to conform to the Poisson model. ${ }^{1}$ It was not possible independently to assess the suitability of the Poisson model for use in our study. The methods of the Dounreay investigators could not be replicated, as the geographical building blocks used in our study were too large to construct suitable areas. The checks made to ensure the validity of the Poisson assumption in the Black and Dounreay reports give some support to its use here. There is no reason to suppose that the area around Hinkley Point should behave any differently in this respect from small rural districts throughout England and Wales or indeed from areas throughout Scotland similar to the area studied around Dounreay.

The results presented for the Hinkley Point area are similar to those relating to other nuclear installations such as Sellafield ${ }^{1}$ and Dounreay ${ }^{6}$ in that there appears to be an excess of cases of leukaemia in young people. The common methodology of the Dounreay and Hinkley Point analyses suggests that the results may be viewed in conjunction with each other. The temporal pattern of the cases in this study contrasts sharply with that found at Dounreay, where the excess cases were concentrated in the most recent period studied rather than the period after commissioning of the station. Nevertheless, it appears that the conclusion of the report on Dounreay when comparing the data with those from Sellafield-namely, that some features of these two plants "leads to an increased risk of leukaemia. .."-could be extended to include Hinkley Point. The nature of the operations at Hinkley Point, however, are very different from those at Sellafield and Dounreay, which contain the only two reprocessing plants in the United Kingdom.

Whether viewed in isolation or in conjunction with results for other nuclear installations, there is no ready explanation for the results relating to Hinkley Point. The possibility that they are simply a chance finding can never entirely be dismissed, but the $p$ values quoted, and in particular the $p$ value for the 1969-73 period, show how unlikely it is that the excess cases were due to random fluctuation. It is important to note that the high incidence of leukaemia was established as 
the result of a prior hypothesis rather than through casual observation.

The suggestion that there is an association between some nuclear establishments and a raised incidence of leukaemia in young people in their vicinity is not a suggestion of a cause and effect relation. Detailed analyses of the Sellafield' and Dounreay data showed that current knowledge regarding exposure to radiation and dose-risk estimates did not permit the possibility that the excess cases of leukaemia could have arisen through radioactive emissions from the nuclear plants. We have briefly examined exposure to radiation in the Somerset area and concluded that radioactive waste disposal from Hinkley Point contributes a small fraction of total exposure. ${ }^{\times}$The timing of the cases of leukaemia in the $12.5 \mathrm{~km}$ area suggests that, if radiation from Hinkley Point was responsible, a large release soon after the first station was commissioned would provide a better explanation than the authorised routine discharges. Though we have not undertaken a complete analysis, it is likely that the release would need to have been thousands of times the annual reported releases. The Central Electricity Generating Board has no record of such a release and Her Majesty's Inspectorate of Pollution confirms that there is no evidence of large scale unreported releases during the 1960s and 1970s.

Though radiation is at present the only known cause of childhood leukaemia, it is almost certain that there are other causes, and indeed many factors may need to be present. Probably at least some types of leukaemia have a virus implicated in their aetiology. A recent study has given some credence to the theory that the high incidence of leukaemia in young people near some nuclear installations could be the result of a large workforce coming together to build the installations, so introducing viruses to a previously isolated community with particular susceptibility. ${ }^{17}$ The study found a high level of mortality from leukaemia in a Scottish new town created over a fairly short period in a previously isolated rural area. The temporal pattern of the cases of leukaemia in the Hinkley Point area fits well with this theory, as the excess cases occurred during the 10 years after the building of the first station.

There are other possible causes for the pattern of cases of leukaemia found in this series-for example, exposure to some unknown toxin causing cancer. Too little is known about leukaemogenesis to draw further conclusions. What seems clear is that it is no longer a question of Do raised levels of leukaemia in young people occur around (some) nuclear installations? but Why? Radiation may remain a possible explanation, but it is well to remember that nuclear establishments have many things in common apart from radioactive emissions, and the observed association may not have a direct cause and effect basis. We intend to conduct further work in an attempt to shed more light on the results presented so far. We shall examine the incidence of other diseases in the area to see whether there is any support for the possibility that radiation could be the cause. We shall attempt to discover more about the people affected to see if they were born in the area and whether they have familial links with any power stations. These results could test the plausibility of both the radiation and virus theories.

We thank staff of the South Western Regional Cancer Registry and the Leukaemia Research Fund for help in data collection.

1 Independent Advisory Group. Investigation of the possible increased incidence of cancer in west Cumbria. London: HMSO, 1984. (Chairman Sir Douglas Black.

2 Roman E, Beral V, Carpenter L, et al. Childhood leukaemia in the West Berkshire and Basingstoke and North Hampshire District Health Authorities in relation to nuclear establishments in the vicinity. Br Med f 1987;294:597602 .

3 Cook-Mozaffari PJ, Ashwood FL, Vincent T, Foreman D, Alderson M. Cancer incidence and mortality in the ricinty of nuclear installations, England
und Wales, 1950-1980. London: HMSO, 1987. (Studies on Medical and und W'ales, 1950-1980. Londor

P'opulation Subjects, No 51.)
Barclay R. (Childhood lcukaemia in Wessex. Community Med 1987;9:279-85

5 Heasman MA, Kemp IW, Urquhart JD, Black R. Childhood leukaemia in northern Scotland. Lancet 1986; i:266.

6 Committee on Medical Aspects of Radiation in the Environment (COMARE). Investigatum of the possible increased incidence of leukaemia in young people near the Dounreay nuclear establishment, Caithness, Scotland. 2nd Report. London: HMSO, 1988 (Chairman Professor M Bobrow.)

7 Bowic C. Lenkuemia in the west of Somerset. Somerset: Somerset Health Authority, 1984

8 Bowie C. Ewings P. Leukuemiu in the west of Somerset: a second report. Somerset: Somerset Health Authority, 1987

9 Ewings $\mathrm{P}$ 'D, Bowie C. Lecukaemia incidence in Somerset with particular reference to Hinkley Point. Somerset: Somerset Health Authority, 1988.

10 Barnes N. Beddall AC, Bird CC, et al. Distribution of leukaemia, lymphoma and allied disease in parts of Great Britain: analssis by administrative districts and simulations of adjacencies. Leeukaemia 1987; $1: 78-81$.

11 Alexander $\mathrm{F}$. Ricketts TJ, McKinney PA, Cartwright RA. Cancer registration Alexander $\mathrm{F}$, Ricketts TJ, McKinney PA, Cartwright RA. Cancer registration
of leukacmias and lymphomas. Results of a comparison with a specialist registry. Communily.Med in press).

12 Glass A G, Hill JA, Miller RW. Significance of clusters. F Pediatr 1968;73: 101-

13 Morris JA, Gardner MJ. Calculating confidence intervals for relative risks odds ratios and standardised ratios and rates. Br Med f 1988;296:1313-6.

14 Swerdlow AJ. Cancer registration in England and Wales: some aspects relevan to interpretation of the data. Fournal of the Roval Statistical Society, series A 1986; 149:1 1+6-60.

15 Bowie $C$. The validity of a cancer register in leukaemia epidemiology. Community Med 1987;9:152-9.

16 Cook-Mozaffari PJ, Darby SC, Doll R, et al. Geographical variation in mortality from leukaemia and other cancers in England and Wales in relation to proximity to nuclear installations, 1969-1978. Br f Cancer 1989;59:476to prox.

17 Kinlen L. Evidence for an infective cause of childhood leukaemia: comparison of a Scottish new town with nuclear reprocessing sites in Britain. Lancet 1988:ii:1323-7.

Accepted 19 Mav 1989

\section{ONE HUNDRED YEARS AGO}

The average age at which children leave elementary schools is 12 in the towns and 11 in the rural districts, but in London the educational period is commonly prolonged to the age of 13; the larger number of these children do not pass beyond the fourth standard. We have about three millions of the pauperised class, and something like another three millions who are just a shade higher in the social scale, and the educational neglect of the children appears to be a main cause of this social defect. It is generally recognised that in Germany the educational system is greatly in advance of our own; all over Germany the attendance at school is universal and compulsory up to the age of 14 for boys. As an extension of the ordinary education there is also a system of evening continuation classes to which children are obliged to go up to the age of 17 . It is suggested that the evening classes should be framed, to a large extent, upon the peculiar needs of the locality where they are opened, and that in rural districts evening classes should only be conducted in the winter, so as not to interfere with the field work of the summer. When the plan was recently brought before the House of Commons by Mr. Samuel Smith, M.P., it met with much general approval, and was supported by Sir Lyon Playfair and Mr. Mundella. All will agree that evening schools may do much good, and we have no desire to raise difficulties, but it will be remembered that Dr. Farquharson had occasion to draw the attention of Parliament to the increase of myopia among school children. Some members of the profession think the danger to eyesight from night work so great for children, that they wish to abolish evening lessons. Mr. S. Smith, and those who desire to found evening continuation classes at board schools, need to consider the hygienic conditions under which their evening classes will be held, both as to eye-conditions, and as to the cleanliness and ventilation of the schools. To quote the success of German learning is not to satisfy us of the safety of uniform evening work for growing lads. Germany is a country of myopics, and many surgeons think that our population is undergoing a like change. Hypermetropic eyes are also exceedingly common among school children, and convergent squints are very frequent. It would, then, be necessary that any school at which it is proposed to hold evening classes should have good artificial lighting, as well as suitable desks for any writing class-work; while it must be remembered that desks and benches must be adapted to the stature of the pupils, and those fitted for young children are not safe for lads of older vears. (British Medical fournal 1889;i:664) 